\title{
Reimagining safety in a pandemic: the imperative to dismantle structural oppression
} in Canada

n Cite as: CMAJ 2020 October 13;192:E1218-20. doi: 10.1503/cmaj.201573

anada's safety record during the coronavirus disease 2019 (COVID-

19) pandemic has exposed longstanding systemic injustices plaguing our society. Knowing that the pandemic and response to it have not affected people equally, we raise the questions: What keeps us safe and who is kept safe during this pandemic?

Does policing people who are systematically oppressed and facing multiple survival challenges (only one of which is COVID-19) keep people safe? Who has the privilege of distancing, whether that means access to a home, car or protective supplies, or the ability to work from home? These questions highlight not only pre-existing social and economic inequities, but also setbacks to achieving a socially just pandemic response.

As medical and public health professionals and members of the People's Health Movement, we believe that everyone deserves safety, a foundational determinant of health. In this article, we use an intersectional race, class and gender lens and consider multiple threats to safety to examine safety in the home, in communities and across borders.

\section{The pandemic of violence against womxn: Is the home safe?}

Globally, people have been encouraged to stay home, implied as the site of safety during this pandemic. Indeed, staying home, thereby minimizing contact, has helped limit the spread of COVID-19 in Canada. But what happens when home is not safe? We have been in a long-standing pandemic of violence against womxn; in
2016, there were 93000 reported cases of intimate partner violence in Canada, with unreported cases likely exceeding reported ones. ${ }^{1}$ COVID-19-related lockdowns and economic shutdowns have drastically exacerbated violence against womxn globally. ${ }^{2}$ For example, Vancouver's Battered Women's Support Services has violence against womxn, most of which occurs in the home. ${ }^{3}$

Feminist activists have long called for multifaceted, community-based solutions to address the complex root causes of violence against womxn, including providing adequate shelter spaces and affordable housing through strategies

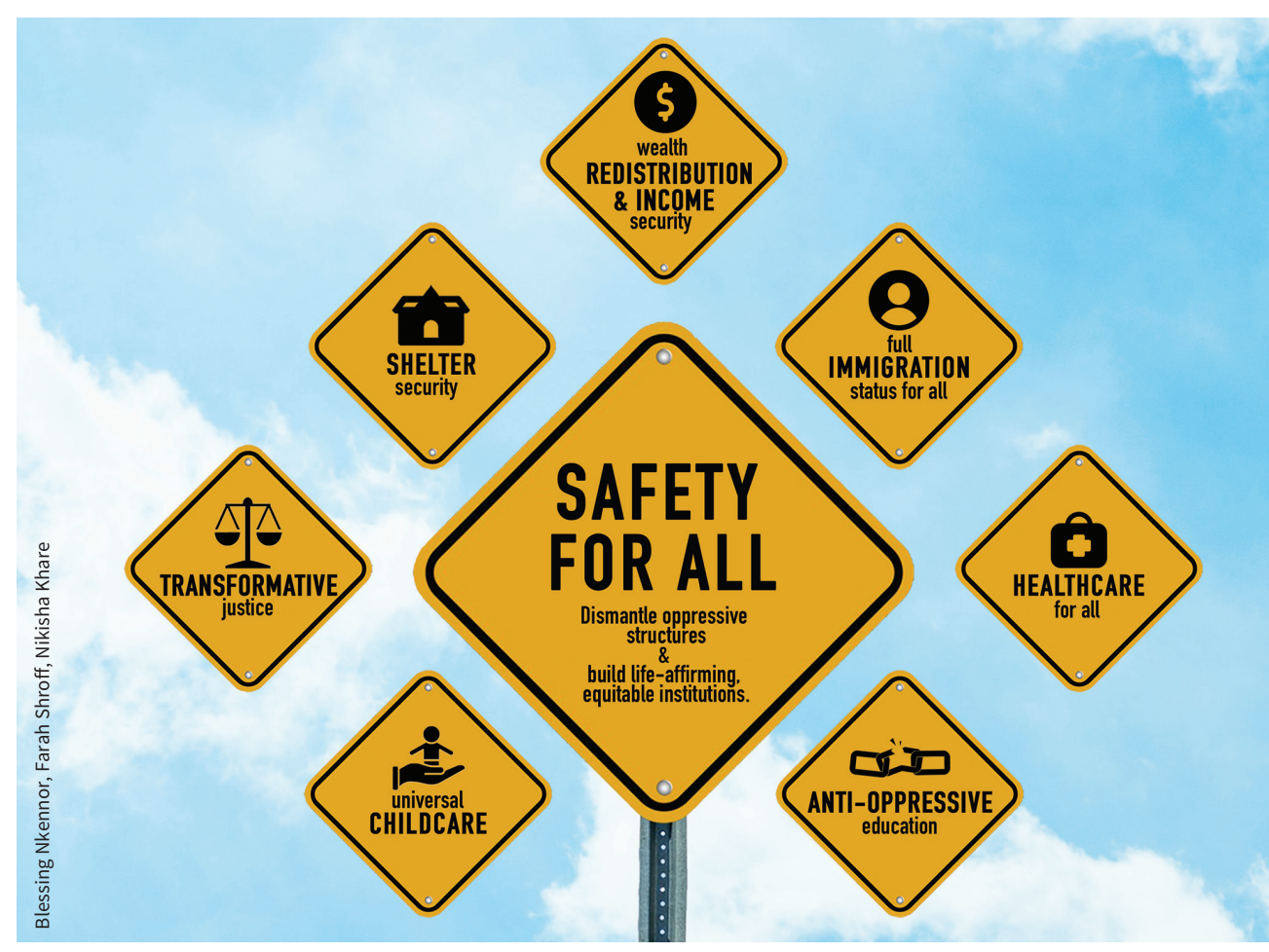

Achieving safety for all.

seen a $300 \%$ increase in calls. ${ }^{2}$ In Canada, 1 in 10 womxn are concerned about violence and do not feel safe at home during COVID-19. ${ }^{2}$ These staggering numbers merit questioning of patriarchal definitions of safety, which have been subject to long-standing feminist critique: the conflation of home and safety invisibilizes such as subsidized units, co-op housing and co-housing; addressing attitudes, behaviours and practices that enable toxic masculinity; and investing in community support and safety measures, including child care, transformative justice and mutual aid networks. The intensification of violence against womxn during 
COVID-19 offers an urgent opportunity to act on these calls ${ }^{3}$ to promote the safety of womxn.

\section{The epidemic of criminalization: Does increased policing make us safer?}

On Apr. 4, a Black father was punched and fined $\$ 2010$ by an Ottawa bylaw officer while in his own neighbourhood with his daughter. ${ }^{4}$ In Quebec and Ontario, people experiencing homelessness have been fined for being unable to physically distance in public spaces. ${ }^{4}$ In Ontario, 2 concerning COVID-19-related expansions of policing powers include an order that enables provincial offences officers to require people to produce identification (ID), with fines up to $\$ 1000$ for failure to do so, and a decision to provide police with access to identifying information and COVID-19 test results. ${ }^{5}$

Although physical distancing recommendations may not be followed for various reasons, decades of research has made clear that those living at intersections of poverty, racialization and/or Indigeneity, among other forms of marginalization, bear the brunt of policing and criminalization. ${ }^{6,7}$ Privileged rule-breakers are not punished in the same way, and measures such as fines do not impose the same burden. ${ }^{8}$

A long history of police violence against Black and Indigenous people and criminalization of poverty in Canada cannot be ignored simply because we are in a pandemic. The recent police killings of D’Andre Campbell, Chantel Moore, Rodney Levi and Ejaz Ahmed Choudry all racialized and Indigenous people demonstrate the tragic, racist violence inherent to Canadian policing. Expanded COVID-19 policing promises to continue racial profiling and violence, crippling punishments for those living in poverty, and criminalization of mental health, addiction and those with precarious immigration status. These groups may not logistically be able to have ID with them, or they may be low-wage workers in essential services or street-involved with no safe place to go. Rather than being supported in their manufactured marginalization, they live with compounded vulnerabilities of economic insecurity, COVID-19 and punitive enforcement, which makes all people less safe from COVID-19. Furthermore, with the criminalization of Black and Indigenous communities having led to disproportionate rates of incarceration, ${ }^{6,7}$ those relegated to prisons are now forced into living conditions optimal for disease transmission, demonstrated by outbreaks in Quebec's and British Columbia's prisons. ${ }^{9}$

Solutions lie in antiracist and anticolonial calls for the defunding of punitive measures and criminalization, with redirection of resources to upstream supports for communities and transformative justice processes, rectifying the social circumstances under which harm is likely to occur.

\section{The crisis of forced displacement: Whose movement is essential?}

On Mar. 20, the Canadian government announced it would turn back refugee claimants crossing the United StatesCanada border. "Irregular" migrants undertaking land crossings are among the most marginalized refugees: those who cannot afford a plane ticket or do not have international agency support. The US continues to detain and deport people at alarming rates, thereby exporting the pandemic to countries with minimal health infrastructure. ${ }^{10}$

Although limiting nonessential travel can be good physical distancing practice, seeking asylum - fleeing poverty, conflict and violence - is arguably the most essential form of travel. Every person has the right to safety (from the aforementioned threats and from the pandemic), regardless of where they live in relation to colonial borders. Both migrants and residents of Canada would be safer if the resources allocated to increased border enforcement were instead directed toward screening and quarantine procedures for migrants upon arrival.

During this pandemic, Canada and other wealthy countries that benefit from the impoverishment and displacement of people in the Global South through various political-economic mechanisms have a duty to expedite acceptance of migrants. This is not only because crises of global displacement are worsening, with 79.5 million people forcibly displaced in $2019,{ }^{11}$ but also because people in refugee camps and immigration detention are especially vulnerable to COVID-19, with little access to water, space or health care.

\section{Who is safe, who is essential and who is sacrificial?}

COVID-19 has spread rapidly among migrant farm workers, meat-packing workers and marginalized health care workers. These jobs, despite being essential to keeping us fed and cared for, are done by highly vulnerable workers.

Canadian temporary foreign worker programs force migrant workers into precariousness through lack of secure immigration status, enabling their exploitation: temporary foreign workers do difficult work that most Canadians do not want to do; live in appalling conditions and earn meagre wages; and have diminished employment rights and no access to services or redress when abuses occur. ${ }^{12}$ Amid widespread COVID19 outbreaks among migrant workers in Ontario, 3 farm workers have died from COVID-19, with activists highlighting preexisting labour and immigration policies responsible for these unjust deaths. ${ }^{13}$

The Alberta Cargill meat-packing plant outbreak, linked to more than 1500 people with COVID-19 among lowwage, mostly racialized immigrant workers, exposed unjust labour practices and prioritization of profits by the corporation. ${ }^{13}$ Furthermore, in Quebec, most workers in long-term care homes are racialized womxn, and in Montréal, thousands of refugee claimants work in longterm care homes - many of them undocumented, living in crowded housing and facing poverty. ${ }^{14}$ This combination of front-line vulnerability and preexisting inequality resulted in an outbreak in the low-income Montréal North neighbourhood. ${ }^{14}$ Not only are such front-line workers vulnerable to COVID-19, but grave risks are posed to those for whom they care.

Although such workers are so essential to society's functioning that they must 
continue to work, they are paid so poorly that they cannot afford to take a sick day, and many do not have access to health care, child care or benefits. Despite filling essential jobs, the workers themselves are treated as disposable.

Various campaigns are advocating for living wages, secure immigration status, paid sick leave, child care, health care for migrants and adequate housing, all of which are key to reducing manufactured inequalities.

\section{Redefining safety for all}

Accepting state-defined pandemic safety measures that do not consider multiple real threats to safety can insidiously lead us to accept systems of patriarchal, racist and economic oppression, exacerbating socioeconomic inequities in Canada. Therefore, we must redefine the meaning of safety ourselves and invest in support for all. We must replace oppressive institutions with equityaffirming ones, with the success of society measured by the well-being of its communities. Directing resources away from punitive measures and toward upstream supports offers the best way forward in achieving safety for all, through this pandemic and beyond.

\section{Nikisha Khare MPH}

Faculty of Medicine, University of Toronto, Toronto, Ont.

\section{Farah Shroff PhD MEd}

Department of Family Practice, and School of Population and Public Health, University of British Columbia, Vancouver, BC

\section{Blessing Nkennor}

Interdisciplinary Centre for Health \&

Society, University of Toronto

Scarborough, Toronto, Ont.

\section{Baijayanta Mukhopadhyay MD MA}

People's Health Movement Canada, Montréal, Que.

\section{References}

1. JustFacts: Intimate partner violence. Ottawa: Department of Justice Canada; modified 2019 Apr. 15. Available: www.justice.gc.ca/eng/rp-pr/jr/ jf-pf/2019/mar01.html (accessed 2020 June 11).

2. Bogart N. Advocates scramble to help domestic abuse victims as calls skyrocket during COVID-19. CTV News 2020 May 3, updated 2020 May 3. Available: www.ctvnews.ca/health/ coronavirus/advocates-scramble-to-help-domestic -abuse-victims-as-calls-skyrocket-during-covid-19 -1.4923109 (accessed 2020 June 11).

3. Stahl A. We have already stopped calling the cops. New York: Bustle; 2020 July 20. Available: www. bustle.com/rule-breakers/police-abolition-domestic -violence?fbclid=IwAROI1dWwFSjVhLXenEgHbvv QqRHrwGN9SfgJE2swST41e5TFBuMaunfj2b8\%20 replace $\% 20$ WHO\%20reference $\% 20$ with $\% 20$ this $\%$ 20 one (accessed 2020 June 11).

4. Jones AM. Report: Fines issued for breaking pandemic measures top $\$ 5.8 \mathrm{M}$, questions raised over 'snitch lines'. CTV News 2020 May 5, updated 2020 May 6. Available: www.ctvnews.ca/canada/report -fines-issued-for-breaking-pandemic-measures-top -5-8m-questions-raised-over-snitch-lines- 1.4926830 (accessed 2020 June 11).

5. COVID-19 and emergency measures in Ontario: everything you need to know. Toronto: Black Legal Action Centre; 2020 Apr. 14. Available: www. blacklegalactioncentre.ca/wp-content/uploads/ 2020/04/COVID-19-and-Emergency-Measures-in -Ontario.pdf (accessed 2020 Aug. 16).

6. Maynard R. Policing Black lives: state violence in Canada from slavery to the present. Winnipeg: Fernwood Publishing; 2017.

7. Crosby A, Monaghan J. Policing Indigenous movements: dissent and the security state. Winnipeg: Fernwood Publishing; 2018.

8. Paradkar S. Shree Paradkar: (Mostly) white covidiots at Trinity Bellwoods think the rules don't apply to them. They're right [opinion]. Mississauga (ON): Mississauga News; 2020 May 24.
Available: www.mississauga.com/opinion-story/ 9995779-shree-paradkar-mostly-white-covidiots -at-trinity-bellwoods-think-the-rules-don-t-apply-to -them-they-re-right/ (accessed 2020 June 11).

9. Inmate COVID-19 testing in federal correctional institutions, August 18, 2020. Ottawa: Correctional Service Canada; modified 2020 Aug. 19. Available: www.csc-scc.gc.ca/001/006/001006-1014-en.shtml (accessed 2020 June 11).

10. Sieff K, Miroff RUS. is deporting infected migrants back to vulnerable countries. The Washington Post 2020 Apr. 21. Available: www.washingtonpost. com/world/the_americas/us-is-deporting-infected -migrants-back-to-vulnerable-countries/2020/04/ 21/5ec3dcfe-8351-11ea-81a3-9690c9881111_story. html (accessed 2020 June 11).

11. Global trends: forced displacement in 2019. Geneva: United Nations Commission on Human Rights; 2020. Available: www.unhcr.org/globaltrends2019/ (accessed 2020 Aug. 13).

12. Bogart N. Advocates demand Ontario shut down farms as COVID-19 cases soar among workers. CTV News 2020 June 29, updated 2020 June 30 Available: www.ctvnews.ca/health/coronavirus/ advocates-demand-ontario-shut-down-farms-as -covid-19-cases-soar-among-workers-1.5004897 (accessed 2020 Aug. 17).

13. Dryden J, Rieger S. Inside the slaughterhouse: North America's largest single coronavirus outbreak started at this Alberta meat-packing plant. Take a look within. CBC News 2020 May 6. Available: https://newsinteractives.cbc.ca/longform/ cargill-covid19-outbreak (accessed 2020 June 11).

14. Bilefsky D. Risking their lives in Canada's pandemic and hoping that's enough to stay. The New York Times 2020 June 12. Available: www. nytimes.com/2020/06/12/world/canada/coronavirus -immigrants.html?auth=login-email\&login=email (accessed 2020 Aug. 16).

This article has been peer reviewed.

Competing interests: None declared.

Acknowledgements: We acknowledge that the land we live on is stolen and continues to be colonized. We stand in solidarity with movements that work to decolonize these lands and that fight for a just society for all. As members of the Canadian chapter of the global People's Health Movement, we acknowledge our members across the globe who are courageously advocating for human rights and health for all. 